\title{
AUSTRALIAN PROPERTY SECURITIES FUNDS: A SURVEY OF STRATEGIC INVESTMENT ISSUES
}

\author{
TAN YEN KENG \\ University of Western Sydney
}

\begin{abstract}
Property securities funds (PSFs) have become increasingly popular, with over $\$ 18$ billion of assets currently being managed by Australian PSFs. Property securities funds include the opportunity to invest in a portfolio of listed property trusts (LPTS) managed by professional fund managers, which allows the investor to achieve diversification across the spectrum of LPTs with reduced portfolio risk. Current practices of PSF managers in making strategic investment decisions, as well as how they manage risk are examined in this study. The results show that an active investment strategy is widely used by the PSF managers and the majority of the respondents are in favour of security selection to asset allocation and market timing. The survey recorded $87 \%$ of the respondents having formal risk management systems and over three quarters of them having crisis management procedures in place. While the number of PSFs currently investing directly in overseas property securities is small, this is expected to increase significantly in the near future as more PSF managers have indicated their intention to venture overseas seeking investment opportunities.
\end{abstract}

Keywords: Property securities fund, listed property trust, investment strategy, risk management.

\section{INTRODUCTION}

Property securities funds (PSFs) have become an increasingly popular form of indirect property investment in Australia in recent years. This is evident with over $\$ 18$ billion in assets currently being managed by PSFs (Property Investment Research (PIR), 2003), which accounts for $2.6 \%$ of the total assets in the Australian managed funds industry (RBA, 2004). Over 45 major investment fund managers (see Exhibit 1) are actively involved in property securities funds.

Securitisation of properties has provided the property sector with enhanced liquidity and divisibility, and multiple-ownership is made possible through broader investor participation. Listed property trusts (LPTs) have been the most successful securitised property investment vehicle in Australia. This is evident in the market capitalisation of LPTs having expanded from $\$ 4.8$ billion in 1991 to $\$ 52$ billion in March 2004, representing over 7.7\% of an average institutional 
investor portfolio (UBS Warburg, 2004). Australian LPTs also make up about 8\% of the world's listed property (ASX, 2002). According to the Australian Stock Exchange 2000 survey (ASX, 2000), LPTs are one of the most popular investments and are directly or indirectly owned by $14 \%$ of adult Australians. This percentage of ownership of LPTs has more than doubled since 1997 (ASX, 2000).

Investors can tap into this successful listed property sector via direct investment in individual LPTs or indirect investment through PSFs. PSFs offer investors the opportunity to invest in a portfolio of property securities (mainly LPTs) managed by professional fund managers with reduced portfolio risk.

The objective of this study is to obtain information for the current practices of Australian PSF managers when making strategic investment decisions, as well as how they manage risk. This study aims to address the strategic investment decision-making process and identify steps taken by the fund managers to reduce property securities investment risk. The findings of this research will contribute to the better understanding of strategic investment choice for property securities investment in Australia.

\section{LITERATURE REVIEW}

Detzler (2002) identified that individual investors commonly rely on fund performance ranking reports published in the popular press for investment advice, due to lack of time and expertise. The better performing funds always have an increased inflow of investment to the funds, which in turn have maximised the funds' value (Chevalier and Ellison, 1997).

Several studies have examined the performance of property securities funds in particular. In Australia, Tan (2003) and Pearce and Newell (1998) found that PSFs generally did not outperform the benchmark. However, over shorter time periods, some PSFs have outperformed the benchmark and added value through asset allocation decisions and portfolio diversification. Comparable studies of property fund performance have been carried out in the UK (Lee, 1999; Lee and Stevenson, 2002) and the USA (Webb and Myer, 1996; Liang and McIntosh, 1998; Myer and Webb, 2000; O'Neal and Page, 2000; Gallo et al, 2000), but the findings are mixed. 
Exhibit 1: Property securities fund managers (June 2003)

\begin{tabular}{|c|c|c|}
\hline Fund Manager & Type & $\begin{array}{c}\text { Total Assets } \\
\text { (AUS Million) }\end{array}$ \\
\hline Advance Fund Management Limited & Retail & 110 \\
\hline AMP Henderson Global Investors Limited & Retail \& Wholesale & 1,391 \\
\hline APN Funds Management Limited & Retail & 636 \\
\hline Australian Unity Funds Management Limited & Retail & 162 \\
\hline Australian Skandia Limited & Wholesale & 35 \\
\hline AUSBIL Dexia Limited & Wholesale & 16 \\
\hline Barclays Global Investors Australia Limited & Retail \& Wholesale & 779 \\
\hline BT Funds Management Limited & Retail \& Wholesale & 1,871 \\
\hline Citigroup Asset Management Australia Limited & Wholesale & 478 \\
\hline Colonial First State Investments Limited & Retail \& Wholesale & 2,772 \\
\hline Credit Suisse Asset Management (Australia) Ltd & Retail \& Wholesale & 345 \\
\hline Deutsche Asset Management (Australia) Limited & Retail \& Wholesale & 2,100 \\
\hline Endeavour Securities (Australia) Limited & Retail & 0 \\
\hline Equity Trustees Limited & Retail & 25 \\
\hline Fiducian Portfolio Services Limited & Retail & 38 \\
\hline Franklin Templeton Investments Australia Ltd & Retail \& Wholesale & 810 \\
\hline Glebe Asset Management Limited & Wholesale & 24 \\
\hline HSBC Asset Management Australia Limited & Wholesale & 723 \\
\hline ING Funds Management Limited & Retail \& Wholesale & 47 \\
\hline Invesco Australia Limited & Wholesale & 162 \\
\hline Intech Fiduciaries Limited & Retail & 120 \\
\hline IOOF Limited & Retail \& Wholesale & 43 \\
\hline Ipac Asset Management Limited & Retail \& Wholesale & 447 \\
\hline James Fielding Funds Management Limited & Wholesale & 139 \\
\hline LM Investment Management Limited & Retail & 3 \\
\hline Macquarie Bank Limited & Wholesale & 681 \\
\hline McLaughlins Financial Services Limited & Retail & 11 \\
\hline MLC Investments Limited & Retail & 1,167 \\
\hline Netwealth Investments Limited & Wholesale & 200 \\
\hline Pengana Capital Limited & Wholesale & 5 \\
\hline Perpetual Investments Management Limited & Retail \& Wholesale & 183 \\
\hline Portfolio Partners Limited & Retail \& Wholesale & 126 \\
\hline Principal Real Estate Investors (Australia) Ltd & Wholesale & 26 \\
\hline Russell Investments Australia Limited & Wholesale & 485 \\
\hline STL Financial Services Limited & Retail & 48 \\
\hline Suncorp Investment Management Limited & Retail & 270 \\
\hline Super Member Investments Limited & Retail & 15 \\
\hline Tower Asset Management Limited & Retail & 74 \\
\hline Trafalgar Managed Investments Limited & Retail & 2 \\
\hline Trust Company of Australia Limited & Retail & 42 \\
\hline UBS Global Asset Management (Australia) Ltd & Retail & 583 \\
\hline Vanguard Investments Australian Limited & Retail & 897 \\
\hline WHTM Capital Management Limited & Wholesale & 5 \\
\hline \multicolumn{2}{|l|}{ Total Assets } & 18,093 \\
\hline
\end{tabular}

Source: PIR (2003)

Pacific Rim Property Research Journal, Vol 10, No 3 
Issues related to fund performance such as performance attribution, size effect, portfolio diversification and risk management are widely researched. Among the performance attribution studies, Stevenson et al (1997) provided evidence that Irish property fund managers' selection ability was negligible, but there was evidence of good market timing. Using UK property funds data, Lee (1997) found most UK property funds demonstrated negative market timing, but these fund managers did exhibit some positive asset selection ability. The empirical evidence on general mutual funds also suggests that managers of mutual funds do not possess good market timing ability (Rao, 2000).

In more recent studies, Lee and Stevenson (2002) found that UK property fund managers did show superior risk-adjusted performance and the out-performance was attributed to managers' selection ability instead of market timing. An Irish property fund performance study by Lee and Stevenson (2003) revealed that property fund managers generally demonstrated poor asset selection ability, while the evidence for superior asset allocation ability was mixed. The empirical evidence from the US (Gallo et al, 2000) and Australia (Tan, 2003) has attributed the better performance of property funds to asset allocation ${ }^{1}$ decisions made by the fund managers, rather than security selection ${ }^{2}$.

Small-firm effects were found to exist in REITs (McIntosh et al, 1991; Liu and Mei, 1992) and in LPTs (Newell and Kishore, 1998), with small and medium property trusts providing better risk-adjusted performance than the large property trusts. However, due to the structural difference in REITs/LPTs and PSFs, small PSFs did not perform as well as large PSFs (Tan, 2003). This finding is in line with the evidence of investment flows between under-performing and outperforming funds (Chevalier and Ellison, 1997).

In a study on property trust portfolio risk, Newell and Acheampong (2001) found that to achieve minimum portfolio risk levels, at least eight property trusts are needed. To reduce the tracking error against the ASX200/ASX300 property index benchmarks, more than thirteen property trusts are required.

The information for investment issues such as investment management strategies and techniques, investment styles, property trust selection criteria; and risk management issues such as investment limitations and risk measures; as well as fund size and benchmarking in current practices of PSF managers are obtained through this survey. The findings of this survey improve the understanding of the strategic investment process and the measures taken to minimise investment risk for property securities investment in Australia.

\footnotetext{
${ }^{1}$ The process of determining the optimal portfolio division among asset classes.

${ }^{2}$ An investment process that identifies which assets to invest in and how much funds to invest in each of the assets.
} 


\section{RESEARCH METHODOLOGY}

The purpose of this survey is to examine the currently applied investment and risk management issues for PSFs. Included are a discussion of issues on investment strategies; selection criteria; benchmarks; international property investment; investment limitations; risk measures; risk management; and cash management for PSFs. A 5-point Likert scale is applied in the questionnaire to determine the importance of a factor/issue.

The sample of PSF managers selected for the study is taken from the Australian Property Funds Industry Survey 2003 (PIR, 2003). The surveys were mailed in November 2003 to all 46 property securities fund managers (both retail and wholesale funds) in Australia as listed in the Australian Property Funds Industry Survey 2003. The author checked the contact details of each survey participant to ensure the survey would be mailed to the correct person in the corporation. A total of 46 surveys were sent out and 15 completed and usable surveys were returned for a response rate of $32.6 \%$.

\section{SURVEY RESULTS AND DISCUSSION}

The total assets under management of the respondents are well over $\$ 9.8$ billion, with about $75 \%$ of the fund assets in wholesale PSFs. The 15 completed surveys accounted for over $30 \%$ of the total assets for retail PSFs and $74 \%$ of the total assets for wholesale PSFs listed in the Australian Property Funds Industry Survey 2003. Among the 15 respondents, 7 offer both retail and wholesale funds. The average number of LPTs held in the PSFs' portfolio is 22, ranging from a minimum of 10 LPTs to the maximum of 30 LPTs.

Exhibit 2: Descriptive statistics of PSF respondents $(n=15)$

\begin{tabular}{|c|c|c|c|}
\hline & $\begin{array}{l}\text { Average Fund } \\
\text { Size }\end{array}$ & $\%$ of Sample & Range of Funds \\
\hline Aggregate Responses & $\$ 655 \mathrm{M}$ & 100 & $\$ 2 \mathrm{M}-\$ 2,660 \mathrm{M}^{2}$ \\
\hline \multicolumn{4}{|l|}{ Size of Fund ${ }^{1}$} \\
\hline$<\$ 500 \mathrm{M}$ & $\$ 78 \mathrm{M}$ & $47(7)$ & $\$ 2 M-\$ 276 \mathrm{M}$ \\
\hline$=>\$ 500 \mathrm{M}$ & $\$ 1,151 \mathrm{M}$ & $53(8)$ & $\$ 500 \mathrm{M}-\$ 2,660 \mathrm{M}^{2}$ \\
\hline \multicolumn{4}{|l|}{ Type of Fund } \\
\hline Retail & $\$ 226 \mathrm{M}$ & $50(11)^{3}$ & $\$ 2 \mathrm{M}-\$ 700 \mathrm{M}$ \\
\hline Wholesale & $\$ 668 \mathrm{M}$ & $50(11)^{3}$ & $\$ 1 \mathrm{M}-\$ 2,382 \mathrm{M}$ \\
\hline \multicolumn{4}{|c|}{$\begin{array}{l}{ }^{2} \text { Total retail and wholesale funds under the same PSF manager } \\
{ }^{3} \text { The total number of retail and wholesale PSFs is } 22(=15+7) \text { due to some respondents having both } \\
\text { retail and wholesale funds. }\end{array}$} \\
\hline
\end{tabular}

Pacific Rim Property Research Journal, Vol 10, No 3 
Exhibit 2 provides a breakdown of the respondent pool by size and type of fund. The average fund size is $\$ 655$ million, but the range is extensive, varying from $\$ 2$ million to over $\$ 2.6$ billion. As would be expected, the larger funds are wholesale funds. The average size of the wholesale funds is $\$ 668$ million, while retail funds average $\$ 225$ million.

\section{Decision-making framework and investment strategy}

Respondents were asked to classify the investment decision-making framework used by their organisation to make PSF investment decisions. Available investment decision-making frameworks were:

1. Top-down approach - where a strategic investment decision was made and investment opportunities were then solicited to conform to target allocations;

2. Bottom-up approach - where investment opportunities were brought to the fund manager and then only after the investment meets the initial objectives and criteria of the fund, the additional strategic portfolio allocations were considered;

3. Combination of bottom-up and top-down approach.

Exhibit 3 compares the three decision-making approaches and investment management strategies. Approximately $46 \%$ of the respondents use a bottom-up investment decision-making approach, while $47 \%$ use a combination of bottom-up and top-down approach. This finding is comparable to Newell and Worzala (1995) and Worzala and Newell (1997) where the majority of the international property investors used a combination approach. The high percentage of PSF managers using a bottom-up approach may be attributable to the relatively small pool of underlying assets (i.e. property securities, particularly Australian LPTs) which makes detailed canvassing of each LPT possible. The top-down approach is the least used in making PSF investment decisions. This is in direct contrast to the direct property investment strategy where the top-down approach is more popular.

Whilst the PSF investment decision-making approach is divided between combination and bottom-up approaches, an active investment management strategy is the most prevalent investment strategy for PSF managers, with $74 \%$ of the respondents using this strategy. Only $26 \%$ of the respondents employed other strategies; i.e. passive or enhanced/hybrid strategy ${ }^{3}$. This finding is in line with the PSF investment management technique, where security selection is perceived as the most important technique compared to asset/sector allocation and market timing (see Exhibit 4). Eighty percent of the respondents rated security selection as a very important or essential investment management technique, while only $21 \%$ and $12 \%$ selecting asset allocation and market timing, respectively.

\footnotetext{
${ }^{3}$ Enhanced/hybrid strategy is a combination of active and passive strategies seeking to provide moderate amount of alpha while keeping tracking error to a minimum.
} 
Exhibit 3: PSF investment decision-making approach and management strategy
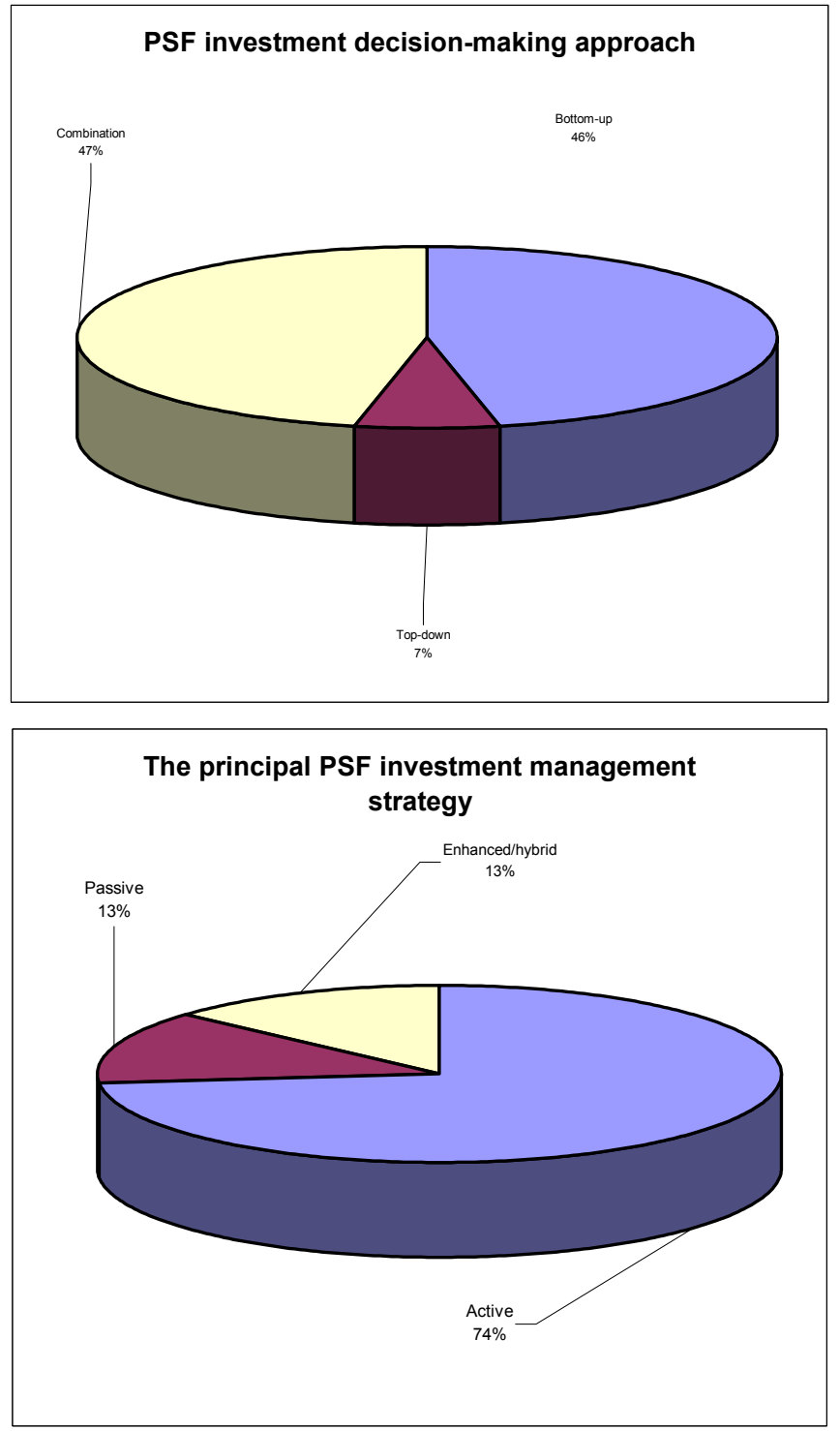
Exhibit 4: Relative importance of investment management techniques (by percentage of respondents rated as very important or essential)

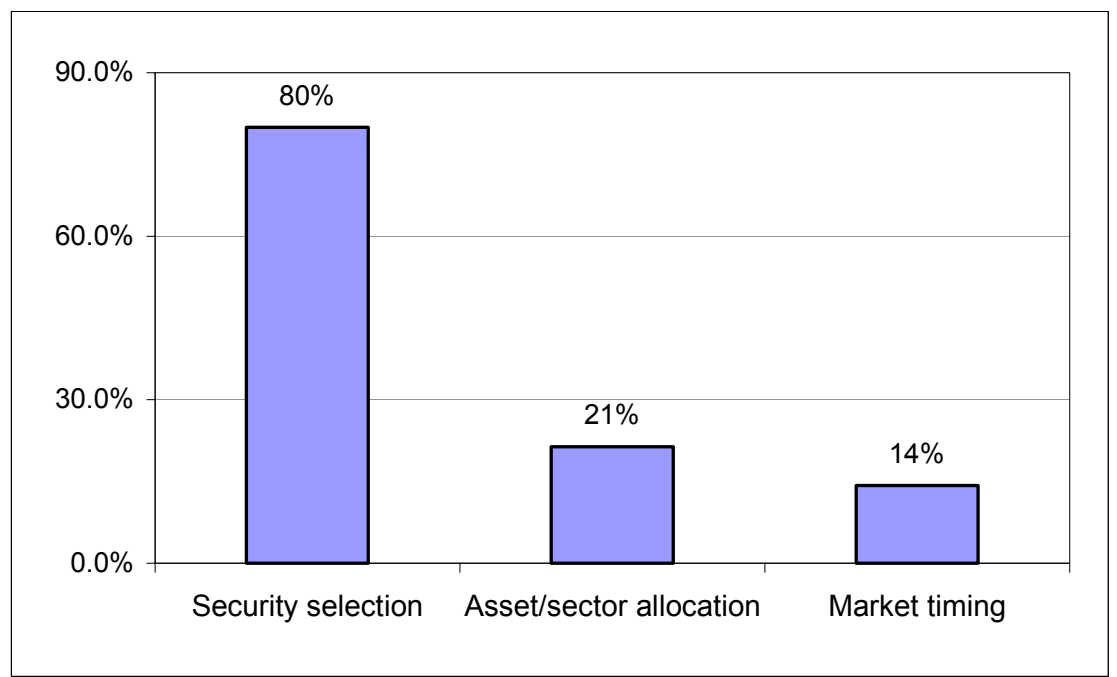

When the relationship between fund size, investment decision-making approach and investment strategy are examined, no clear linkages are found. However, for investment techniques, all the large PSF respondents (>\$500 million) regard security selection as the essential technique, whilst less than $60 \%$ of the smaller PSFs ( $<\$ 500$ million) are of the same opinion. A possible explanation to this finding is that large PSFs have more resources in researching each of the individual LPTs to ensure the successful implementation of security selection investment technique compared to small PSFs.

\section{Portfolio allocation and management}

As suggested by the fund's classification and mandate, not many PSFs have allocations for assets other than property securities. Only $13 \%$ and $20 \%$ of the respondents invested in direct property and property syndicates, respectively. The main reasons for allocations in direct property and property syndicates are to enhance portfolio returns and to reduce portfolio volatility. However, about $60 \%$ of the respondents do invest in property-related securities such as developer, contractor and infrastructure stocks and the essential reasons quoted are portfolio return enhancement and increased investment opportunities. No clear linkage is found between portfolio allocation and PSF fund size.

$74 \%$ of the respondents' PSF portfolios are managed by in-house managers. Only $13 \%$ are managed by outside managers. The balance of $13 \%$ is managed by both in-house and outside managers. Over two thirds of the respondents' organisations 
have other property investment funds besides a PSF, but these property investment funds are managed separately to the PSFs.

Over $93 \%$ of the respondents use both in-house and external research reports when making PSF investment decisions. About 53\% use both, but mainly in-house research, and $20 \%$ use both, but mainly external research. Only $7 \%$ of the respondents solely rely on in-house research in formulating their PSF investment strategy.

\section{Size effect}

Over $92 \%$ of the respondents believed fund size affects performance and $62 \%$ of them believed performance affects fund size. However, about two thirds of the respondents agreed that there is no causal relationship between fund size and performance.

When asked about the perceived optimum number of property securities to be included in their PSF, the responses were very diverse, ranging from 10 LPTs to 'the more the better', with the average of 23 property securities. Again, the perceived optimal fund size ranged from $\$ 15$ million to over $\$ 1$ billion, or $2 \%$ of the LPT market capitalisation, with the mode of around \$1 billion.

\section{Investment styles}

Exhibit 5 compares the investment styles employed by the PSF managers. Longterm focus and value-focus are the two most commonly used investment styles. This result is expected as the characteristics of the underlying investment asset, property securities, are long-term and value in nature. Trailing closely is a growth focus investment style, which is common among active fund managers. Other investment styles employed include index tracking, growth at a reasonable price (GARP), aggressive buy/sell; style neutral and yield focus are also used in PSF investment. The majority (53\%) of the respondents employed more than one investment style in managing their PSF. The relationship between investment style and fund size was examined but no clear linkage was found.

As depicted in Exhibit 6, the fundamental investment management approach is rated by $77 \%$ of the respondents as a very important investment management approach. About $67 \%$ and $54 \%$ of the respondents viewed a qualitative approach and portfolio construction-based techniques as essential, whilst $23 \%$ of the respondents rated a quantitative approach and tilts ${ }^{4}$ as very important investment management approaches. A volatility-based investment management approach is rated as not important. No distinctive difference in investment management approach is found between large and small PSFs.

${ }^{4}$ Overweight the portfolio toward a particular style of a particular factor.

Pacific Rim Property Research Journal, Vol 10, No 3 
Exhibit 5: Currently employed investment styles by PSF managers

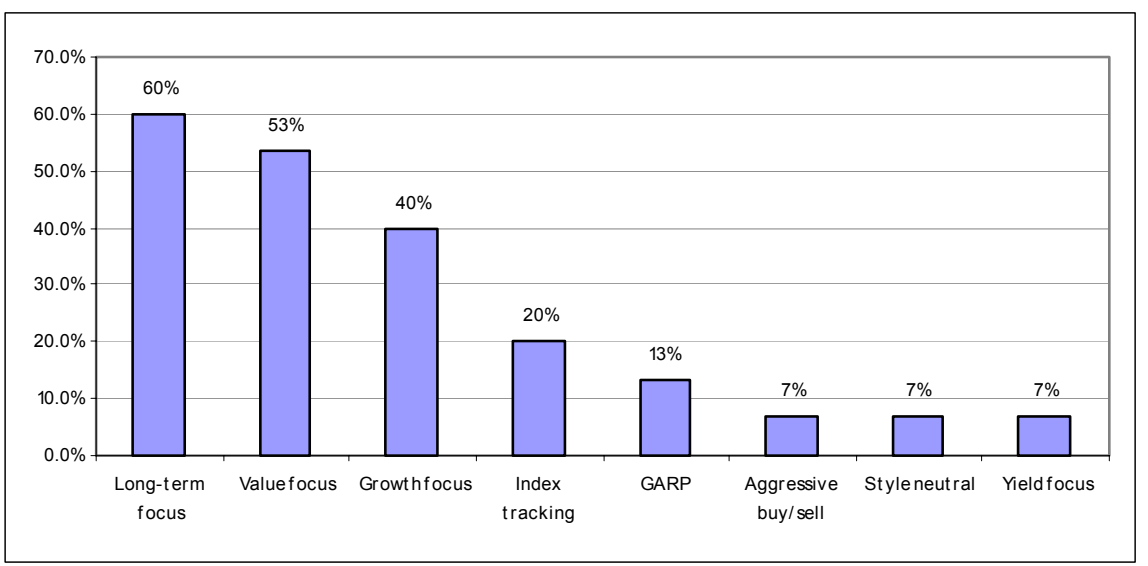

Exhibit 6: Relative importance of investment management approach (by percentage of respondents rated as very important or essential)

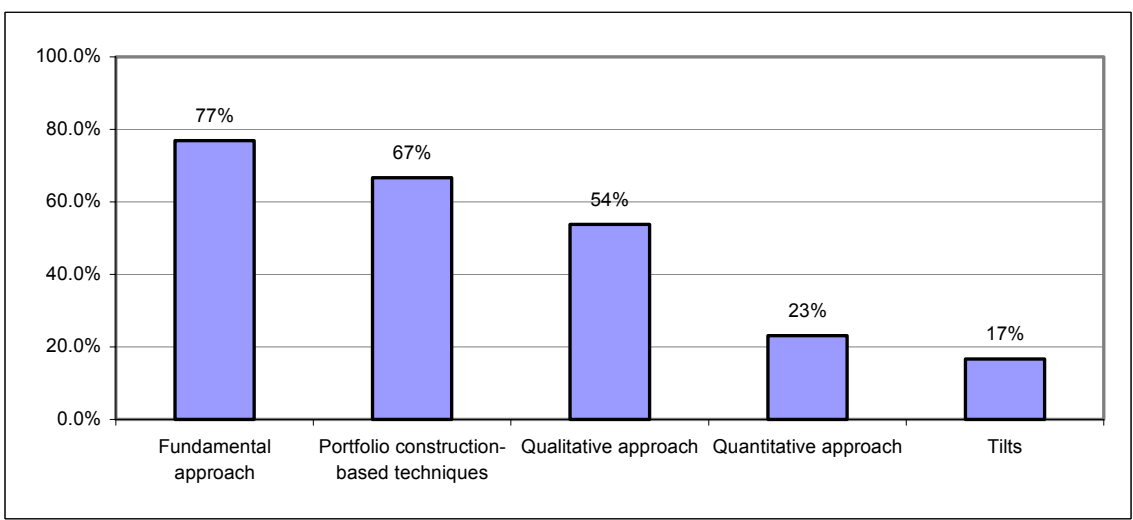

\section{Property trust selection criteria}

About $40 \%$ of the respondents do not target all listed property trusts. Property trusts to be included in the PSF portfolios are selected based on certain criteria. Among the selection criteria, value and expected return of a property trust are rated by most of the respondents as the essential selection criteria (see Exhibit 7). Other selection criteria such as diversification benefit, trust liquidity and trust size are rated as important selection criteria, while taxation benefits of difference trusts is not considered as an important selection criteria by most of the respondents. No clear linkage is found between selection criteria and PSF fund size. 
Exhibit 7: Relative importance of the selection criteria (by percentage of respondents rated as very important or essential)

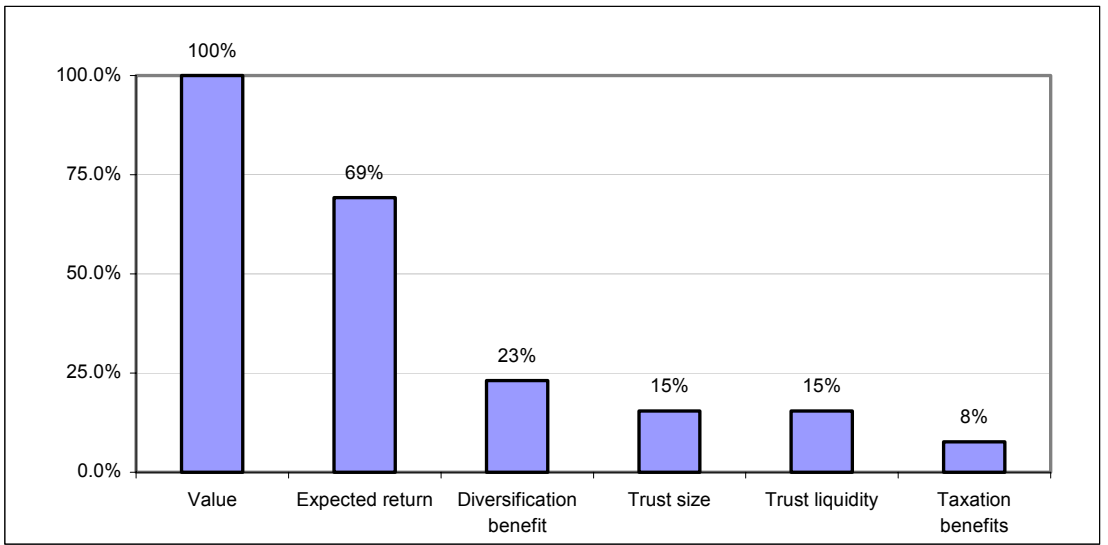

\section{Risk management: formal investment limitations}

About $87 \%$ of the respondents have a formal risk management system in place for their PSF, and $80 \%$ of the respondents' organisations have an enterprise-wide or firm-wide risk management system. Over a third of the respondents use derivatives in their PSF risk management and about half of the respondents have formal written guidelines for the application of derivatives. Over $78 \%$ of the respondents have a crisis management system or contingency plan.

Among the three risk management programs/software used in managing PSF risk, in-house programs are the most widely used $(77 \%) ; 62 \%$ of the respondents use BARRA $^{5}$ and only $15 \%$ use HiPort $^{6}$ risk management programs.

Exhibit 8 shows the list of formal investment limitations and the percentage of the respondents imposing these formal investment limitations. As depicted in Exhibit $8,92 \%$ of the respondents have formal limitations on cash holdings. The maximum allocation allowed for cash ranged from 5\% - 20\%. The second most imposed limitation is on the allocation to a single property trust, with the majority of the formal limitations set within $\pm 10 \%$ of the index weighting.

${ }^{5}$ BARRA is a financial risk management software developed and supported by Barra.

${ }^{6} \mathrm{HiPort}$ is an investment risk management program. 
Exhibit 8: Formal investment limitations

\begin{tabular}{|c|c|c|}
\hline $\begin{array}{l}\text { INVESTMENT } \\
\text { LIMITATIONS }\end{array}$ & \% Imposing & FORMAL LIMITATION \\
\hline Cash & $92 \%$ & $\begin{array}{cl}\text { Maximum allocation: } \\
- & 5 \%-20 \% \text { in PSF portfolio } \\
- & \text { majority at } 10 \%\end{array}$ \\
\hline $\begin{array}{l}\text { Allocation to a single } \\
\text { property trust }\end{array}$ & $85 \%$ & $\begin{array}{ll}\text { Maximum allocation: } \\
-\quad \text { index } \pm 5 \%-10 \% \\
-\quad 10 \% \text { if the trust has }<10 \% \\
\\
\quad \text { weight in index } \\
-\quad 2-3 \text { times the index }{ }^{1} \text { weight } \\
-\quad 15 \% \text { of issued capital } \\
-\quad 1 / 3 \text { of the market value } \\
-\quad 20 \% \text { of trust's net assets }\end{array}$ \\
\hline $\begin{array}{l}\text { Investment in direct } \\
\text { property }\end{array}$ & $83 \%$ & $\begin{array}{l}\text { No allocation to direct property, or } \\
\text { maximum allocation: } \\
-\quad 10 \%-15 \% \text { in PSF portfolio }\end{array}$ \\
\hline $\begin{array}{l}\text { Investment in property } \\
\text { syndicate }\end{array}$ & $83 \%$ & $\begin{array}{l}\text { No allocation to property syndicates, or } \\
\text { maximum allocation: } \\
-\quad 10 \%-20 \% \text { in PSF portfolio }\end{array}$ \\
\hline $\begin{array}{l}\text { Investment in property } \\
\text { related securities }\end{array}$ & $75 \%$ & $\begin{array}{l}\text { No allocation to other property } \\
\text { securities, or maximum allocation: } \\
\begin{aligned}- & 5 \%-25 \% \text { in PSF portfolio } \\
- & \text { index } 1 \pm 5 \% \\
- & <5 \% \text { in one property-related } \\
& \text { security }\end{aligned}\end{array}$ \\
\hline Investment in LPT & $39 \%$ & $\begin{array}{l}\text { Maximum allocation: } \\
-\quad \text { index }{ }^{1} \pm 5 \%-10 \% \\
-\quad 10 \% \text { if the trust has }<10 \% \\
\\
\text { weight in index } \\
-\quad 5 \% \text { of sector capitalisation } \\
-\quad 100 \% \text { in LPTs }\end{array}$ \\
\hline $\begin{array}{l}\text { Number of property trusts } \\
\text { in portfolio }\end{array}$ & $36 \%$ & $\begin{array}{c}\text { Minimum number of trusts: } \\
-\quad 10-25 \\
-\quad \text { average of } 15\end{array}$ \\
\hline Fund size & $29 \%$ & $\begin{aligned} \text { Maximum fund size: } \\
-\quad \$ 1 \text { billion }-\$ 2.5 \text { billion } \\
-\quad 2 \% \text { of the sector capitalisation }\end{aligned}$ \\
\hline Type of property trusts & $23 \%$ & $\begin{array}{l}\text { Maximum allocation to each type: } \\
-\quad \text { index }{ }^{1} \pm 5 \%-10 \%\end{array}$ \\
\hline Property sectors & $15 \%$ & $\begin{array}{l}\text { Maximum allocation to each sector: } \\
-\quad \text { index }{ }^{1} \pm 10 \%-15 \%\end{array}$ \\
\hline
\end{tabular}

${ }^{1}$ refers to the respective benchmarks used by the PSFs i.e. S\&P/ASX 200 (300) Property Trust Index and S\&P/ASX 200(300) Property Accumulation Index. 
As found earlier, the respondents largely do not invest in direct property and property syndicates; hence, most of the formal limitations on these investments are restricted at $0 \%$ allocation. For those respondents who are allowed to invest in these investment assets, the maximum allocation is confined to $10 \%-20 \%$. Quite a number of respondents are allowed to invest in property-related securities, but the limit is constrained at between $5 \%-25 \%$ of their overall PSF portfolio.

Although not many respondents are bound by formal investment limitations on numbers of property trusts allowed in their portfolio, for those who do have formal limitations, the minimum number of property trusts in the PSF is between 10-15. Not many respondents are restricted by the fund size. However, for those who have restrictions, the maximum fund size is capped at $\$ 1$ billion- $\$ 2.5$ billion, or $2 \%$ of the overall LPT sector capitalisation.

Less than a quarter of the respondents have formal limitations on the allocations to property type and property sector. The usual formal limitation for both property type and property sector is between $\pm 5 \%$ to $\pm 15 \%$ of the index weight.

Over $90 \%$ of the respondents, at the time of completing this survey, have LPTs that contain international property, stapled-securities structure ${ }^{7}$ LPTs, and leveraged LPTs, which are perceived as more risky compared to the traditional externally managed LPTs, in their portfolio. Less than $15 \%$ of the respondents have limitations on investing in international, stapled-securities structure and leveraged LPTs, where the limitations are mainly on:

- $\quad$ multiple of the index ${ }^{8}$;

- $\quad$ LPTs that have more than $20 \%$ invested in offshore (ex NZ);

- $\quad$ LPTs that have more than 25\% earnings derived from non-leasing activities; and

- $\quad$ certain gearing and interest coverage requirements.

Only $14 \%$ of the PSFs can use leverage to enhance their PSF return, but the maximum leverage allowed is capped at between 30\%-60\%.

\section{Risk management: risk measures}

Exhibit 9 compares the relative importance of risk measures. The most highly regarded risk measure is tracking error, which is rated by over $60 \%$ of the respondents as the essential risk measure for their PSF. However, when fund size is taken into consideration, only $38 \%$ of the large funds ( $>\$ 500$ million) rated tracking error as the very important risk measure, compared to $71 \%$ of the small funds

${ }^{7}$ A stapled-securities structure LPT is usually formed via stapling the units in the property trust to the shares of the management company e.g. Stockland and Mirvac.

${ }^{8}$ refers to the respective benchmarks used by the PSFs i.e. S\&P/ASX 200 (300) Property Trust Index and S\&P/ASX 200(300) Property Accumulation Index.

Pacific Rim Property Research Journal, Vol 10, No 3 
( $<\$ 500$ million). This finding is consistent with the PSF investment management techniques where more large PSFs compared to small PSFs regard security selection as the essential technique partly due to the security selection technique may result in significant performance deviation from the underlying benchmarks used in tracking error measurement.

Other commonly used risk measures such as variance, information ratio, riskadjusted ratio are also deemed as important in PSF risk measurement. Alternative risk measures such as semi-variance, downside risk, tail loss and value at risk (VAR) are rated by the majority of the respondents as less important.

Exhibit 9: Relative importance of risk measures (by percentage of respondents rated as very important or essential)

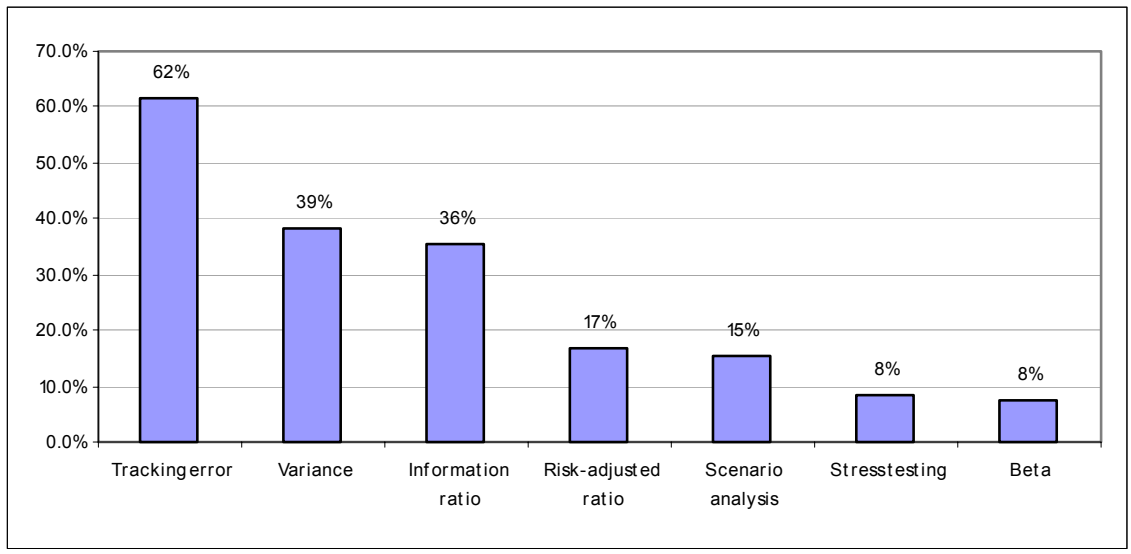

Exhibit 10: Relative importance of risk

\begin{tabular}{|l|c|}
\hline Risk & Importance Score* \\
\hline Business risk & 3.36 \\
\hline Operational risk & 3.36 \\
\hline Market risk & 3.21 \\
\hline Liquidity risk & 3.07 \\
\hline Legal risk & 2.62 \\
\hline Credit risk & 2.50 \\
\hline
\end{tabular}

$* 1=$ Not Applicable; 2 = Not Important; $3=$ Important $; 4=$ Very Important $; 5=$ Essential .

The respondents were asked to rate the importance of several risks when managing their PSF. Exhibit 10 lists the PSF risks in accordance to their importance score. Business risk and operational risk are regarded as the more important risks in 
managing PSFs. Market and liquidity risks are considered as important, whilst legal risk and credit risk are deemed as less important. This finding is expected as the performance of the underlying PSF investments, i.e. LPTs, is highly influenced by the aggregate property market's demand and supply, property type and geographic allocations, the efficiency of the LPT manager, as well as the liquidity provided by certain large LPTs.

\section{Cash management and derivatives}

Over $50 \%$ of the respondents have a systematic technique to reduce cash drag, where the most popular technique used is cash management funds $(46.1 \%)$, followed by futures contracts $(30.8 \%)$. The introduction of the ASX LPT futures contract in August 2002 have provided PSF managers with an effective cash drag management instrument.

None of the respondents use options to manage cash drag, and less than $8 \%$ of the respondents use index funds, swap and synthetic positions to manage cash drag. Other techniques used include gearing, holding minimal cash $(<1 \%)$ and maintaining being fully invested.

\section{Review frequency and benchmark}

Two thirds of the respondents review their PSF investment strategy at least once a month and over $90 \%$ of the respondents rebalance their portfolio at least once a week or when necessary. Over $70 \%$ of the respondents trade at least once a week if not more frequently.

About $50 \%$ of the respondents benchmark against the S\&P/ASX 200 Property Trust Index and $40 \%$ benchmark against the S\&P/ASX 300 Property Accumulation Index, while the balance of $10 \%$ use the S\&P/ASX 200 Property Accumulation Index as their performance standard. Over $86 \%$ of the respondents are required to outperform their respective benchmarks, with the majority required to outperform by at least $1 \%$ to $2 \%$.

\section{Direct international property securities investment}

As over $55 \%$ of domestic Australian investment grade property is held in LPTs, some LPTs are forced to look for investment opportunities overseas (Calder, 2002; BDO, 2004). The 2004 BDO survey (BDO, 2004) reported 25\% of the LPTs' investments are in overseas properties. It is expected in the coming years that a significantly higher percentage of LPT assets will be located overseas. This development will see international property investment becoming an indispensable segment of the Australian LPT industry (BDO, 2004) and international property investment will become the main source of LPT sector growth (Larsen, 2004).

As more LPTs invest internationally, this development has offered new investment options to Australian investors, especially smaller fund managers who have no 
resources and expertise to invest directly in international property, to gain international property investment exposure for their investment portfolios (Tan, 2004). As McAllister (2000) concluded, indirect investment in specialist property securities offers a more suitable method of gaining exposure to international property markets.

When asked about whether LPTs with international property holding is a good substitute for direct investment in overseas property securities, $60 \%$ of the respondents agreed with the statement. Rationales given included:

- $\quad$ appropriately structured tax for Australian investors;

- some of the currency risk is managed/hedged by the international LPT manager;

- $\quad$ better management quality with overseas expertise;

- liquidity and diversification benefits of having exposure to a portfolio of properties via international LPTs;

- $\quad$ one gets the earnings exposure without the foreign equity market exposure, currency risk is a negative but compensated for by greater depth of higher quality property.

On the other hand, the other $40 \%$ of the respondents did not agree that international LPTs are a good substitute for direct international property securities investment, quoting:

- lack of liquidity;

- not a substitute because the risk profile and strategies are completely different;

- international LPTs provide exposure to selected overseas property markets, whilst overseas property securities provide exposure to specific overseas property and equity markets;

- additional layer of fees for the investor.

As depicted in Exhibit 11, about a quarter of the respondents are currently investing directly in overseas property securities, mainly in REITs in the US, Europe, Asia, Canada, and countries in the Citigroup World Property Index (i.e. US, Canada, Continental Europe, UK, Asia, Japan). Reasons for investing in international property securities include:

- broader investment universe and more opportunity;

- $\quad$ part of existing global property securities fund;

- $\quad$ permissible by the fund constitution;

- enhance diversification across countries, economic cycles and property sectors. 
Exhibit 11: Direct international property securities investment (by percentage of respondents)

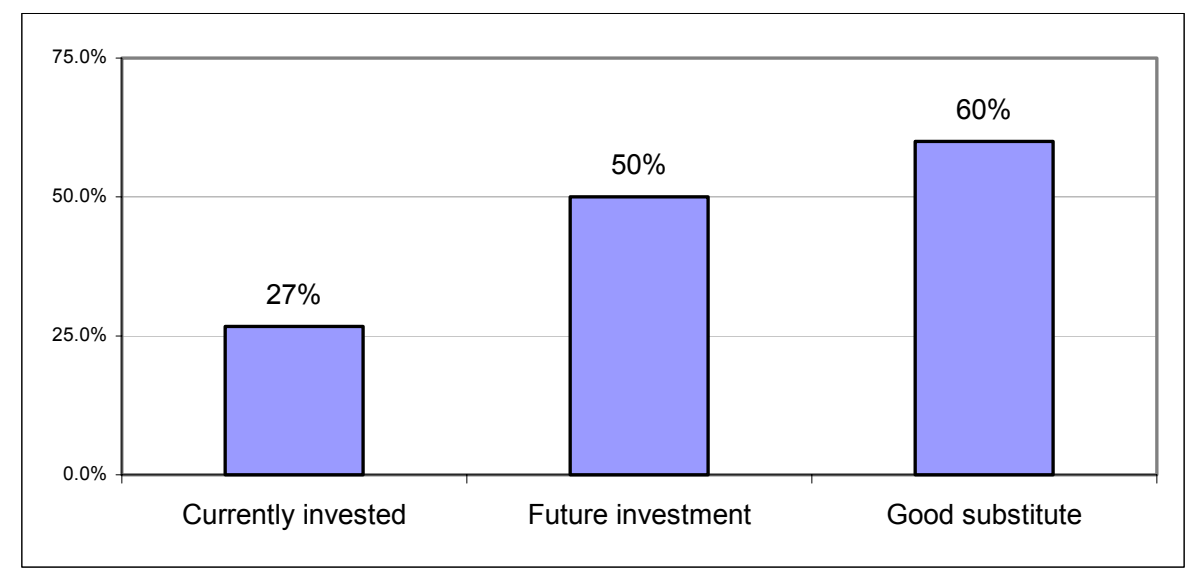

Fifty percent of the respondents have intentions to invest or continue to invest directly in international property securities in the future. Their focus is on REITs in the US, Europe, Japan, UK, Hong Kong, Singapore and several countries in Asia.

The examination of direct international property securities investment in relation to fund size did not reveal any clear connection between the two. However, $71 \%$ of the large PSF respondents ( $>\$ 500$ million) did reveal their interest in future direct international property securities investment.

\section{CONCLUSIONS}

With a large amount of evidence being available concerning the performance attributes of property funds, limited information is available concerning the actual investment strategy and risk management for PSFs. This survey has provided some insights on currently applied PSF investment decisions and how risk is managed.

An active investment strategy is widely used by the PSF managers and the majority of the respondents are in favour of security selection over asset allocation and market timing. Over $86 \%$ of the respondents are required to outperform their respective benchmarks, with the majority required to outperform by at least $1 \%$ to $2 \%$. The popular investment styles employed are long-term focus and value focus, whilst the most sought-after characteristics of a property security are potential value and the expected return. 
Over $87 \%$ of the respondents have formal risk management procedures, whilst over three quarters of them have a crisis management system in place. The investment risk is mitigated through portfolio diversification and imposition of formal limitations on cash holdings, allocation to LPTs, direct property, property syndicates and property-related securities. Tracking error, variance and information ratio are regarded as the more important measurements of risk.

While the number of PSFs currently investing directly in international property securities is small, this is expected to increase significantly in the near future as more PSF managers have expressed their intention to venture overseas seeking investment opportunities. Their focus is on REITs in the US, Europe, Japan, UK, Hong Kong, Singapore and several countries in Asia.

\section{REFERENCES}

Australian Stock Exchange. 2000. 2000 Australian share ownership study. ASX: Australia.

Australian Stock Exchange. 2002. Property Trusts Summary: Listed Property Trusts. ASX: Australia.

BDO. 2004. BDO Listed Property Trust Survey 2004 Edition. BDO Chartered Accountants and Advisers: Australia.

Calder, S. 2002. Offshore Investment Opportunities. BT Real Estate Fund Management: Australia.

Chevalier, J. and Ellison, G. 1997. Risk taking by mutual funds as a response to incentives. Journal of Political Economy, Vol. 105, No. 6, 1167-1200.

Detzler, M. 2002. The value of mutual fund rankings to the individual investor. Journal of Business \& Economic Studies, Vol. 8, No. 2, 48-72.

Gallo, J., Lockwood, L. and Rutherford, R. 2000. Asset allocation and the performance of real estate mutual funds. Real Estate Economics, Vol. 28, No. 1, $165-184$

Larsen, C. 2004. Interview with Mark Steinert: the growth guru. Property Australia, April, 18-21.

Lee, S. 1997. The components of property fund performance. Journal of Real Estate Portfolio Management, Vol. 3, No. 2, 97-105. 
Lee, S. 1999. Style analysis and property fund performance. Journal of Property Investment and Finance, Vol. 17, No. 2, 145-157.

Lee, S. and Stevenson, S. 2002. A meta analysis of real estate fund performance. Paper presented at ARES Annual Meeting, Naples, Florida, USA.

Lee, S. and Stevenson, S. 2003. Empirical evidence on the micro and macro forecasting ability of real estate funds. Journal of Property Research, Vol. 20, No. 3, 207-234.

Liang, Y. and McIntosh, W. 1998. REIT style and performance. Journal of Real Estate Portfolio Management, Vol. 4, No. 1, 69-78.

Liu, C. and Mei, J. 1992. The predicability of returns on equity REITs and their comovement with other assets. Journal of Real Estate Finance and Economics, Vol. 5, 401-418.

McAllister, P. 2000. Is direct investment in international property market justifiable? Property Management, Vol. 18, No. 1, 25-29.

McIntosh, W., Liang, Y. and Tompkins, D. 1991. An examination of the smallfirm effect within the REIT industry. Journal of Real Estate Research, Vol. 6, No. 1, 9-17.

Myer, F. and Webb, J. 2000. Management styles of REIT funds. Journal of Real Estate Portfolio Management, Vol. 6, No. 1, 339-348.

Newell, G. and Acheampong, P. 2001. Portfolio construction and risk management in property securities funds. Pacific Rim Property Research Journal, Vol. 7, No. 4. 285-295.

Newell, G. and Kishore, R. 1998. Analysis of property trust performance issues. Proceeding of $4^{\text {th }}$ PRRES Conference, Perth, 1998.

Newell, G. and Worzala, E. 1995. The role of international property in investment portfolios. Journal of Property Finance, Vol. 6, No. 1, 55-63.

O'Neal, E. and Page, D. 2000. Real estate mutual funds: abnormal performance and fund characteristics. Journal of Real Estate Portfolio Management, Vol. 6, No. 3, 239-248.

Pearce, P. and Newell, G. 1998. The performance of property securities funds: 1991-96. Proceeding of $4^{\text {th }}$ PRRES Conference, Perth, 1998. 
Property Investment Research. 2003. Australian Property Funds Industry Survey 2003. PIR: Melbourne.

Rao, U. 2000. Market timing and mutual fund performance. American Business Review, Vol. 18, No. 2, 75-79.

Reserve Bank of Australia, 2004. Reserve Bank of Australia Bulletin: March 2004.

Stevenson, S., Kinsella, R. and Healai, R. 1997. Irish property funds: empirical evidence on market timing and selectivity. Irish Business and Administrative Research, Vol. 18, 167-177.

Tan, Y. K. 2003. Performance analysis of Australian property securities funds. Pacific Rim Property Research Journal, Vol. 9, No. 2, 104-120.

Tan, Y. K. 2004. Benchmarking international property in Australian listed property trust portfolios. Pacific Rim Property Research Journal, Vol. 10, No. 1, 3-29.

UBS Warburg 2004. UBS Warburg Indices: March 2004 (and miscellaneous copies). UBS Warburg: Sydney.

Webb, J. and Myer, F. 1996. Management style and asset allocation in real estate portfolios. Journal of Real Estate Portfolio Management, Vol. 2, No. 2, 119-125.

Worzala, E. and Newell, G. 1997. International real estate: a review of strategic investment issues. Journal of Real Estate Portfolio Management, Vol. 3, No. 2, $87-96$. 